\title{
Synergistic anti-HIV-1 activity of griffithsin with tenofovir, maraviroc and enfuvirtide
}

\author{
Geoffrey Férir ${ }^{1 *}$, Kenneth E Palmer ${ }^{2}$, Dominique Schols ${ }^{1}$ \\ From Frontiers of Retrovirology 2011 \\ Amsterdam, The Netherlands. 3-5 October 2011
}

\section{Background}

More than $60 \%$ of the total HIV-1 infections worldwide are dominated by clade B and C. To stop the epidemic, effective prevention methods (e.g. microbicidal gel) are of extreme importance. Carbohydrate binding agents (CBAs) are very good microbicide candidates. We previously showed that various CBAs act synergistic with tenofovir against HIV-1 [1].

Griffithsin (GRFT), isolated from the red alga Griffithsia sp., shows very potent and broad-spectrum anti-HIV activity and recombinant forms can easily be produced $[2,3]$.

\section{Materials and methods}

HIV-1 replication was measured in MT-4 cells and peripheral blood mononuclear cells (PBMCs) by MTS method and p24 Ag ELISA respectively. Synergism was calculated using CalcuSyn software (Biosoft, Cambridge, UK) based on the median effect principle [4]. Combination indices $(\mathrm{CI})<0.9$ are synergistic, $0.9<\mathrm{CI}<1.1$ are additive and $\mathrm{CI}>1.1$ are antagonistic.

\section{Results}

We evaluated combinations of GRFT against HIV-1 clade $B$ and clade $C$ isolates with various glycosylation patterns on the viral envelope in PBMCs and MT-4 cells. In all combinations tested against clade $B$ viruses BaL (R5) and NL4.3 (X4), GRFT showed synergistic activity with tenofovir, maraviroc, AMD3100 and enfuvirtide, based on the median effect principle with combination indices $(\mathrm{CI})$ varying between 0.34 and 0.64 at the calculated $\mathrm{EC}_{95}$-level. Against the clade $\mathrm{C}$ viruses, ZAM18, DJ259 and ETH2220 (all R5), Cl-values varied between 0.70 and 0.79 . The $\mathrm{CI}$ correlated with increased antiviral activity of each individual compound.

${ }^{1}$ Rega Institute for Medical Research, Katholieke Universiteit Leuven, Leuven, Belgium

Full list of author information is available at the end of the article

\section{Conclusions}

The evaluated two drug combinations increase their antiviral potency and support further clinical investigation and evaluation in preexposure prophylaxis in the context of HIV-1 clade B and clade C infections. Difference in glycosylation motifs in gp120 have little, if any, effects on the antiviral activity of GRFT.

\section{Acknowledgements}

This work was supported by the K.U. Leuven (GOA no. 10/014, EF/05/15 and $\mathrm{PF} / 10 / 018$ ), the FWO (no. G.48S.08), the CHAARM project of the European Commission and the Dormeur Investment Ltd. Manufacture of GRFT was supported by NIH grant Al076169 to K.E. Palmer.

\section{Author details}

${ }^{1}$ Rega Institute for Medical Research, Katholieke Universiteit Leuven, Leuven, Belgium. ${ }^{2}$ Department of Pharmacology and Toxicology and Owensboro Cancer Research Program, James Graham Brown Cancer Center, University of Louisville School Of Medicine, Louisville, USA.

Published: 3 October 2011

\section{References}

1. Férir G, Vermeire K, Huskens D, Balzarini J, Van Damme EJ, Kehr JC, Dittmann E, Swanson MD, Markovitz DM, Schols D: Synergistic in vitro anti-HIV type 1 activity of tenofovir with carbohydrate-binding agents (CBAs). Antiviral Res 2011, 90:200-204.

2. Mori T, O'Keefe BR, Sowder RC 2nd, Bringans S, Gardella R, Berg S, Cochran P, Turpin JA, Buckheit RW Jr., McMahon JB, Boyd MR: Isolation and characterization of griffithsin, a novel HIV-inactivating protein, from the red alga Griffithsia sp. J Biol Chem 2005, 280:9345-9353.

3. O'Keefe BR, Vojdani F, Buffa V, Shattock RJ, Montefiori DC, Bakke J, Mirsalis J, d'Andrea AL, Hume SD, Bratcher B, et al: Scaleable manufacture of HIV-1 entry inhibitor griffithsin and validation of its safety and efficacy as a topical microbicide component. Proc Natl Acad Sci USA 2009, 106:6099-6104.

4. Chou TC, Talalay P: Quantitative analysis of dose-effect relationships: the combined effects of multiple drug or enzyme inhibitors. Adv Enzyme Regul 1984, 22:27-55.

doi:10.1186/1742-4690-8-S2-O36

Cite this article as: Férir et al:: Synergistic anti-HIV-1 activity of griffithsin with tenofovir, maraviroc and enfuvirtide. Retrovirology 2011 8(Suppl 2): O36.

\section{() Biomed Central}

(c) 2011 Férir et al; licensee BioMed Central Ltd. This is an open access article distributed under the terms of the Creative Commons Attribution License (http://creativecommons.org/licenses/by/2.0), which permits unrestricted use, distribution, and reproduction in any medium, provided the original work is properly cited. 